\title{
Trace-element and physical response to melt percolation in Summit (Greenland) snow
}

\author{
Gifford J. WONG, Robert L. HAWLEY, Eric R. LUTZ, Erich C. OSTERBERG \\ Dartmouth College, Sherman Fairchild Hall, Hanover, NH, USA \\ E-mail: gifford.wong@gmail.com
}

\begin{abstract}
Surface melt on a glacier can perturb the glaciochemical record beyond the natural variability. While the centre of the Greenland ice sheet is usually devoid of surface melt, many highArctic and alpine ice cores document frequent summertime melt events. Current hypotheses interpreting melt-affected ice-core chemistry rely on preferential elution of certain major ions. However, the precise nature of chemistry alteration is unknown because it is difficult to distinguish natural variability from melt effects in a perennially melt-affected site. We use eight trace-element snow chemistry records recovered from Summit, Greenland, to study spatial variability and melt effects on insoluble trace chemistry and physical stratigraphy due to artificially introduced meltwater. Differences between non-melt and melt-affected chemistry were significantly greater than the spatial variability in chemistry represented by nearest-neighbour pairs. Melt-perturbed trace elements, particularly rare earth elements, retained their seasonal stratigraphies, suggesting that trace elements may serve as robust chemical indicators for annual layers even in melt-affected study areas. Results suggest trace-element transport via meltwater percolation will deposit eluted material down-pit in refrozen areas below the nearest-surface chemistry peak. In our experiments, snow chemistry analyses are more sensitive to melt perturbations than density changes or unprocessed near-infrared digital imagery.
\end{abstract}

\section{INTRODUCTION}

Studies of ice-core trace-element glaciochemistry have contributed to our understanding of natural climate change and documented the impact of human activities on climate over the last few centuries (e.g. Murozumi and others, 1969; Hong and others, 1994; Lambert and others, 2008). Interpretations of ice-core chemical records collected from regions that experience seasonal melting must account for postdepositional processes resulting from meltwater percolation and refreezing (Koerner, 1997). Understanding meltwaterrelated glaciochemical effects is increasingly important, especially within a warming climate, as ice-core records contain climate histories from areas that have experienced or are currently experiencing melt. Specific to the Greenland ice sheet (GIS), for example, a distinct, ice-sheet-wide, melt event occurred in summer 2012; the last occurrence of such an event was in 1889 (Clausen and others, 1988; personal communication from K. Keegan, 2012). We present a field study that quantifies the effect of melt processes on snow chemistry while accounting for natural variability.

Meltwater develops on an ice field when sustained high air temperature or high radiative flux melts snow at or near the surface (Langway, 1967). Meltwater then travels down from the surface through the snowpack according to initial structure and conditions (e.g. Pfeffer and Humphrey, 1998; Waldner and others, 2004). Vertical penetration via flow 'fingers' tends to terminate into lateral flow at snow layer interfaces (McGurk and Kattelmann, 1988; Williams and others, 2010). When the meltwater reaches snow layers that are sufficiently cold to induce refreezing, vertical ice fingers and horizontal ice layers are preserved that have been used as a paleoclimate proxy for relative regional summertime temperatures in ice cores (Herron and others, 1981; Alley and Anandakrishnan, 1995; Das and Alley, 2008; Hanna and others, 2008; Kelsey and others, 2010). However, the movement of meltwater through the snowpack can also distort ice-core paleoclimate records based on glaciochemical time series (Legrand and Mayewski, 1997) by altering chemical concentrations and reducing vertical (and therefore temporal) variability (Koerner, 1997). Early work by Davies and others (1982) demonstrated the preferential elution (i.e. downward mobilization and removal) of sulfuric and nitric acid in a Norwegian snowpack during early meltseason thaw. Brimblecombe and others (1985) and Tsiouris and others (1985) established an elution order in which $\mathrm{NO}_{3}{ }^{-}, \mathrm{SO}_{4}{ }^{2-}, \mathrm{Mg}^{2+}$ and $\mathrm{K}^{+}$are removed from a seasonal snow cover preferentially over $\mathrm{Na}^{+}$and $\mathrm{Cl}^{-}$. Using this observed melt-related behaviour, lizuka and others (2002) and Virkkunen and others (2007) developed useful indicators for melt by examining the relationship between $\mathrm{Mg}^{2+}$ and $\mathrm{Na}^{+}$in melt-affected ice-core records from Svalbard.

While meltwater percolation homogenizes soluble majorion chemistry, reducing the seasonal variations often used for dating purposes, comparatively little is known about the effects of melt percolation and refreezing on trace-element glaciochemistry, particularly insoluble aerosols. Koerner (1977) noted that insoluble microparticles tend to aggregate along melting surfaces in glaciers prone to seasonal melting, enriching concentrations of microparticles at the meltwater front. Steffensen (1985) observed possible size fractionation of microparticles during melting and refreezing at Dye 3, South Greenland, and Zdanowicz and others (1998) hypothesized that ice layers might serve as a barrier against microparticle migration in snow at Penny Ice Cap, Arctic Canada. Ice core studies increasingly use trace elements to develop records of atmospheric pollution (e.g. Osterberg and others, 2008; Liu and others, 2011), volcanic activity (e.g. Narcisi and others, 2006) and dust provenance and transport mechanisms (e.g. Hong and others, 1996; Bory and others, 2003). This increasing use of trace-element time series has stemmed from improved techniques in traceelement sample collection and analysis (Boutron and others, 
1994; McConnell and others, 2002; Osterberg and others, 2006; Bigler and others, 2011). Thus an understanding of the effect of melting on trace-element chemistry is of increasing importance, particularly in a warming climate with increased surface melting.

Previous studies investigating melt effects on snow and ice glaciochemistry interpreted chemistry signals after seasonal melt had occurred (e.g. lizuka and others, 2002; Pohjola and others, 2002). To address the lack of an experimental control with pristine, melt-free snow, Virkkunen and others (2007) compared snow-pit data collected during consecutive field seasons in Svalbard to capture snow chemistry that had not been altered by melt, and Fortner and others (2009) took bulk samples from fresh, winter snow and ablation snow in consecutive field campaigns on Eliot Glacier, Oregon Cascades, USA. However, these studies were performed on heavily melt-affected glaciers, and thus were unable to investigate the chemical modification of in situ melt percolation and refreeze by comparing snow chemistry before and after melt penetration in the same snow pit.

Here we investigate the impact of meltwater percolation on snow-pit chemistry at Summit, Greenland, an area of the GIS that is not prone to seasonal melting (Alley and Anandakrishnan, 1995). We conducted four artificial melt experiments to directly compare pristine and melt-affected snow. By conducting our investigation in the dry snow zone of the ice sheet (Benson, 1962) and assuming low glaciochemical variability due to horizontal homogeneity at the $10 \mathrm{~m}$ scale, we seek to examine and characterize the effects of meltwater percolation and refreezing on dust trace-element distribution in near-surface snow.

\section{METHODS}

\section{Study site location and climatology}

Our study site was near Summit Camp, Greenland $\left(72.6^{\circ} \mathrm{N}\right.$, $38.5^{\circ} \mathrm{W} ; 3200 \mathrm{~m}$ a.s.I.), $28 \mathrm{~km}$ west of the GIS summit. The mean annual accumulation at Summit is $\sim 24.0 \pm 0.5 \mathrm{~cm}$ w.e. $a^{-1}$ (Meese and others, 1994), with a mean annual temperature of $-32^{\circ} \mathrm{C}$ (Drab and others, 2002). Alley and Anandakrishnan (1995) investigated melt feature incidence in the deep Greenland Ice Sheet Project 2 (GISP2) ice core from a nearby site and observed a frequency of one melt event per 250 years over the last $3 \mathrm{ka}$.

\section{Experimental design}

We conducted a total of four melt experiments in separate snow pits to investigate the influence of percolating and refreezing meltwater on trace-element chemistry. We arranged the four snow pits in pairs separated by $6 \mathrm{~km}$; neighbouring pits were $10 \mathrm{~m}$ apart. Thus, each experiment has one neighbour experiment $10 \mathrm{~m}$ away, and two experiments $6 \mathrm{~km}$ away.

For each melt experiment, we filled a pre-cleaned polyethylene carboy with surface snow collected from the top $3 \mathrm{~cm}$ of the snowpack. The snow was melted inside the carboy in a heated, interior space, and then cooled until the temperature of the meltwater approached $0^{\circ} \mathrm{C}$. We constructed a meltwater applicator consisting of a perforated, $1 \mathrm{~m}$ long narrow plastic cylindrical sleeve, sealed at one end and open at the other, using low-density polyethylene 'layflat' plastic (typically used to protect ice cores during transport). Both the carboy and applicator were triple-rinsed with MilliQ $(>18.2 \mathrm{M} \Omega)$ deionized water before use. We

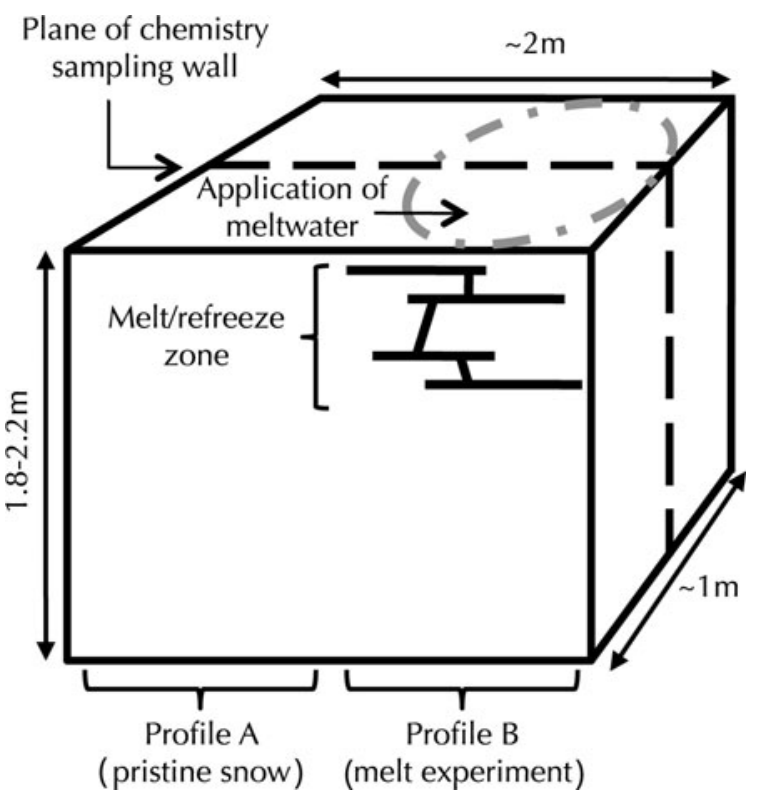

Fig. 1. Perspective schematic of our experimental set-up. We applied meltwater to the surface snow. We excavated the snow pit so that the chemistry sampling wall was approximately bisecting the meltwater application area as illustrated by the dashed line. The pristine snow is represented by profile $A$, and the melt experiment is represented by profile $B$.

applied $\sim 15 \mathrm{~L}$ of meltwater across an $80 \times 80 \mathrm{~cm}^{2}$ area of the snow surface for each melt experiment. This amount of melt application conservatively approximates an annual melt percentage of $10 \%$. The meltwater was allowed to penetrate into the snow for 2-4 hours in pits 1-3 before sampling, and for 33 days in pit 4 . Although the amount of water applied and its rate of application is not representative of typical melt events at our field site, we aimed to supply sufficient water to allow for water infiltration through at least 1 year of accumulated snow. This also allowed for infiltrating meltwater to interact with impeding stratigraphic features, such as impermeable layers or grain-size transitions that act as capillary barriers, both of which would allow for refreeze to be more easily observed on a subsequent pit wall.

We subsequently excavated a 1.5-2.0 m deep snow pit at each experiment site, oriented such that the chemistry sampling wall was upwind and bisected the area where meltwater was applied (Fig. 1). We verified meltwater penetration by physical observation of melt features (e.g. melt fingers and ice lenses) in each snow pit. For each snow pit, we sampled two vertical profiles at $3 \mathrm{~cm}$ vertical resolution for chemical analysis. We positioned the profiles $\sim 50 \mathrm{~cm}$ apart, such that one profile sampled snow influenced by meltwater percolation and refreeze, and the other sampled snow unaffected by meltwater penetration. Hence, we sampled a total of eight glaciochemical snow profiles, four of which were influenced by melt and four of which were not. Here, we will refer to the unaffected, pristine profile in each pit as 'profile $A^{\prime}$, and the meltwateraffected profile in each pit as 'profile B'.

We sampled the snow pits for chemistry wearing nonparticulating Tyvek ${ }^{\circledR}$ suits and polyethylene gloves (cf. Twickler and Whitlow, 1997). The samples were collected in polyethylene bottles pre-cleaned with $20 \%$ nitric acid baths (cf. Osterberg and others, 2006) and stored frozen until melting prior to chemical analysis. We digitally 


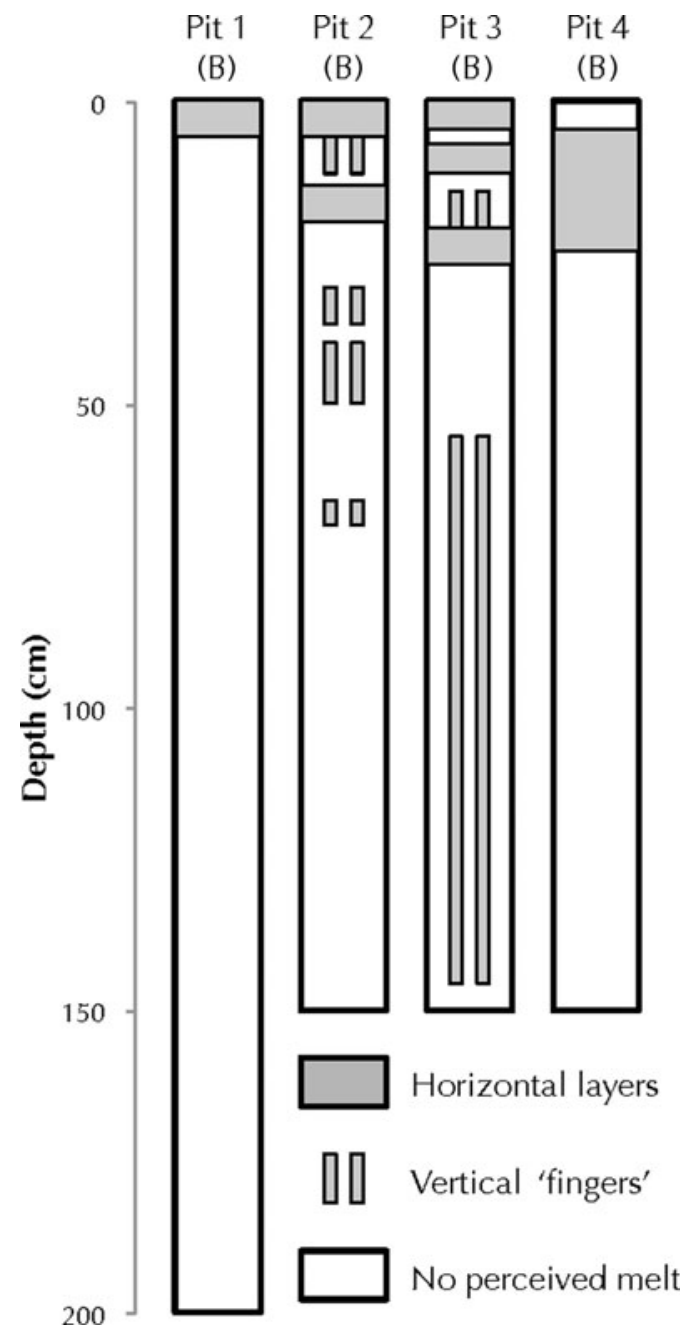

Fig. 2. Summary representation showing the stratigraphic results of the four melt percolation experiments. Melt and refreeze effects were observed in the top few centimetres of all four snow pits. Pits 2 and 3 exhibited meltwater infiltration via vertical flow fingers, which brought meltwater to greater depths below the surface than observed in pit 1 or 4 . Pit 4 appeared to experience more vertical penetration of meltwater than pit 1 ; observed refreeze was horizontal and close to the surface.

photographed the snow-pit walls in the visible and nearinfrared $(850 \mathrm{~nm})$ spectra, and measured snow densities at $10 \mathrm{~cm}$ vertical resolution for each profile in each snow pit using a $1000 \mathrm{~cm}^{3}$ cutter. Sections where melt features prevented full insertion of the density cutter were allocated the maximum density observed across the eight profiles $\left(0.46 \mathrm{~g} \mathrm{~cm}^{-3}\right)$. We melted snow samples under a class 100 HEPA (High Efficiency Particle Air) clean bench and acidified them to $1 \%$ by weight for a 4 week period with ultrapure (Optima) nitric acid. The concentrations of trace elements were measured at the University of Maine, USA, by inductively coupled plasma sector field mass spectroscopy (ICP-SMS; Thermo Scientific Element2) (cf. Osterberg and others, 2006). We focus here on trace elements associated with insoluble dust $\left({ }^{24} \mathrm{Mg},{ }^{27} \mathrm{Al},{ }^{44} \mathrm{Ca},{ }^{47} \mathrm{Ti}\right.$, ${ }^{55} \mathrm{Mn},{ }^{56} \mathrm{Fe},{ }^{59} \mathrm{Co},{ }^{88} \mathrm{Sr},{ }^{133} \mathrm{Cs},{ }^{139} \mathrm{La},{ }^{140} \mathrm{Ce}$ and ${ }^{141} \mathrm{Pr}$ ) because they exhibit a strong springtime peak representing elevated dust transport from Asia (Steffensen, 1988; Whitlow and others, 1992; Mosher and others, 1993; Biscaye and others, 1997; Bory and others, 2002) and serve as a consistent annual marker.

\section{Comparing snow-pit melt effect against natural variability}

To isolate the effect of meltwater penetration on dust traceelement glaciochemistry against a background of natural spatial variability, three of the eight profiles were needed for each melt experiment. We compare the differences between the pristine $(\mathrm{A})$ and melt-affected $(\mathrm{B})$ profiles of a snow pit to the variance between that snow pit's profile $A$ and the nearest neighbouring snow pit's profile A. We examine measured concentrations of elements as well as their calculated masses, based on measured concentrations and density. To exclude variability potentially caused by machine uncertainty, we first filtered the concentration data so that values below the detection limit (cf. Osterberg and others, 2006) were set to a minimum value based on laboratory blanks.

To ensure our analysis was examining snow that was deposited in the same year across all four snow pits, we applied a 'moving window' statistical analysis at a $50 \mathrm{~cm}$ stratigraphic scale. By selecting a window size that is smaller than the annual snow accumulation, we evaluated consecutive seasonal peaks independently. We incremented this analysis window down-pit by our sampling interval $(3 \mathrm{~cm})$ to create continuous statistical analyses of dust trace elements along the entire height of the snow pits. Use of a large window overlap (i.e. 94\% between adjacent windows) can allow patterns in the statistical analysis to be attributed to stratigraphic features (in contrast, applying non-overlapping window analysis does not aid in this purpose) (Lutz and others, 2007).

Here we describe the statistical procedure that was applied separately for each element measurement (concentration or mass) in each $50 \mathrm{~cm}$ stratigraphic window. A $50 \mathrm{~cm}$ window contains 17 samples. First we calculate the mean difference between depth-paired measurements of adjacent $A$ and $B$ profiles $\operatorname{mean}_{B-A}$. This quantifies the average difference between the pristine and melt-affected profile within that stratigraphic $3 \mathrm{~cm}$ interval. Then the natural variability $u_{\text {nat }}$ of the same stratigraphic interval is estimated from the variance of the differences between depth-paired measurements of the nearest pristine profile (10 $\mathrm{m}$ away). Lastly, to determine if the meltwater treatment has an effect that is greater than the natural variability, a Student's $t$ test is performed to estimate the likelihood that mean $_{B-A}$ could have occurred by chance when the population variance is equal to $u_{\text {nat }}$.

Ideally $u_{\text {nat }}$ is estimated from paired pristine profiles that are separated by the same distance as the paired profiles in the meltwater comparison. Assuming that natural variability increases with distance, our $10 \mathrm{~m}$ scale estimates of $u_{\text {nat }}$ are likely larger than the natural variability occurring at adjacent profiles $(0.5 \mathrm{~m})$ scale. Hence we likely overestimate $u_{\text {nat }}$ and thereby cause the $t$ test to conservatively reject possible meltwater effects as natural variability.

\section{RESULTS}

\section{Physical snowpack changes resulting from melt percolation}

Visual observations (field observations and qualitative interpretation of imagery) and the physical sampling process revealed that the four snow pits show variability in the vertical distribution, thickness and patterns of ice layers and vertical ice pipes representing refrozen meltwater (Fig. 2). 
The melt experiment in pits $2-4$ produced observable melt features extending below $3 \mathrm{~cm}$ depth (Figs 2 and 3), whereas in pit 1 observable melt features were limited to the upper $3 \mathrm{~cm}$. Horizontal ice lenses and vertical ice fingers are both present in pits 2 and 3, with observed meltwater penetration reaching depths of 66 and $141 \mathrm{~cm}$, respectively. Conversely, pit 4 developed a shallow concentration of refrozen meltwater and horizontal ice lenses between 6 and $21 \mathrm{~cm}$ with no visible vertical ice fingers.

Another method of determining where meltwater may have migrated within the snowpack is to compare density profiles of pristine and melt-affected snow. The average densities of profiles $A$ and $B$ were very similar, with the meltaffected profiles an average of $0.01-0.02 \mathrm{~g} \mathrm{~cm}^{-3}$ denser than the pristine profiles (Fig. 4), due to the addition of $15 \mathrm{~L}$ of meltwater. Discrete ice layers were difficult to measure accurately with the snow density cutters, introducing 20$30 \%$ error to the density measurements. Except for the thick packet of ice lenses in pit 4, melt layers were typically much smaller than our $10 \mathrm{~cm}$ snow cutter and heterogeneously distributed (e.g. melt fingers of pits 2 and 3).

We determined the depths at which significant density changes occurred by comparing the densities from profile B of each snow pit to the average densities derived from the four A profiles. Density intervals in a profile B were considered significantly different if they were greater than the $95 \%$ confidence limit about the mean density of the four A profiles at the same depth (Fig. 4). Assuming significant changes in density were a result of meltwater intrusion and not natural variability, we can identify areas of the nearsurface snowpack that have undergone densification via meltwater refreezing. Increases in density ranged between $13 \%$ and $74 \%$; however, this includes a density interval from pit 2 that could not be directly sampled in the field due to thick melt features. The density assigned to this interval was the highest measured density across the four snow pits $\left(0.46 \mathrm{~g} \mathrm{~cm}^{-3}\right)$. Removing this density interval reduces the densification factor to $13-34 \%$.

\section{Chemical snowpack changes resulting from melt percolation}

All eight chemistry profiles exhibit a strong seasonality, with annual trace-element peaks corresponding to the springtime peak in Asian dust deposition (Drab and others, 2002). Averaged over the entire depth of the snow pits, the elemental concentrations in pristine snow are greater and more variable than in melt-affected snow, with the exception of ${ }^{56} \mathrm{Fe}$ and ${ }^{59} \mathrm{Co}$ (Table 1). To examine the effect of melt percolation of snow chemistry in more detail, we compare melt-affected and pristine chemical concentrations in $50 \mathrm{~cm}$ moving windows and focus on the springtime dust peaks in 2010 and 2009. In all four snow pits, most trace elements in the melt-affected profiles show lower (by 1-48\%) spring 2010 peak concentrations and higher (by 1-47\%) spring 2009 peak concentrations than in their paired pristine profiles. For example, spring 2010 peak concentrations of ${ }^{88} \mathrm{Sr}$ in all four snow pits are diminished by $11-47 \%$ in the melt-affected profiles (Fig. 5). Conversely, spring 2009 peak concentrations of ${ }^{88} \mathrm{Sr}$ are enriched by $1-32 \%$ in the meltaffected profiles. This behaviour reflecting melt-induced transport from the 2010 spring dust peak to lower depths in the snowpack (the 2009 annual layer) is consistently observed for each element in each snow pit with a few exceptions. For example, ${ }^{44} \mathrm{Ca},{ }^{55} \mathrm{Mn}$ and ${ }^{59} \mathrm{Co}$ in the
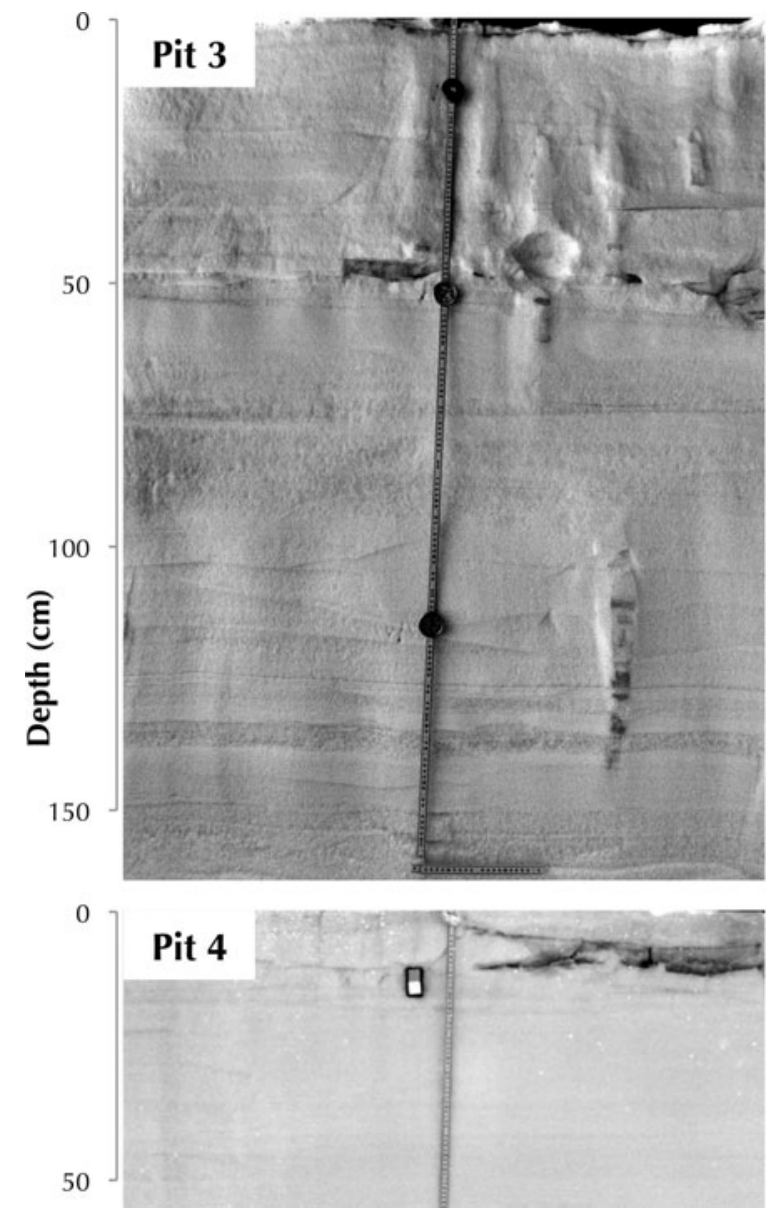

Fig. 3. Processed near-infrared images of meltwater penetration and refreeze formed in pits 3 and 4 at Summit Camp. While both snow pits received the same meltwater treatment, pit 4 was excavated a month after meltwater application. Dark areas indicate zones of meltwater percolation and refreeze. Also visible are many of the stratigraphic layers present in the snow pits. Images are adjusted for ambient lighting variations and scaled to Spectralon calibration targets.

melt-affected profile of pit 4 shows enrichment in both springtime peaks (0-14\%), despite showing depleted meltaffected 2010 peaks in pits $1-3$. Similarly, ${ }^{133} \mathrm{Cs},{ }^{139} \mathrm{La}$, ${ }^{140} \mathrm{Ce},{ }^{141} \mathrm{Pr},{ }^{27} \mathrm{Al},{ }^{47} \mathrm{Ti},{ }^{55} \mathrm{Mn},{ }^{56} \mathrm{Fe}$ and ${ }^{59} \mathrm{Co} 2009$ peak concentrations were diminished by $2-11 \%$ in pit 2 , despite enrichment in the other pits. ${ }^{56} \mathrm{Fe}$ in pit 4 shows a much larger (113\%) enrichment of the 2010 springtime peak, which appears to be due to contamination from the meltwater applicator. For each element analysed, the changes in calculated mass are similar to changes in measured concentration described above.

\section{Natural spatial variability of snow chemistry versus melt-induced chemistry changes}

To incorporate the natural variability of trace-element snow chemistry at Summit into the analysis of melt effects, we compare chemistry changes in melt-affected snow to the calculated variance between nearest-neighbour pristine snow profiles. This places any calculated difference between pristine and treated snow into the context of $10 \mathrm{~m}$ scale variability. Strong seasonal variations in trace-element concentrations (masses) are present in both profiles $\mathrm{A}$ and $B$ in every snow pit. Some seasonal signals show a $\sim 3 \mathrm{~cm}$ vertical offset in pristine profile A compared with the 


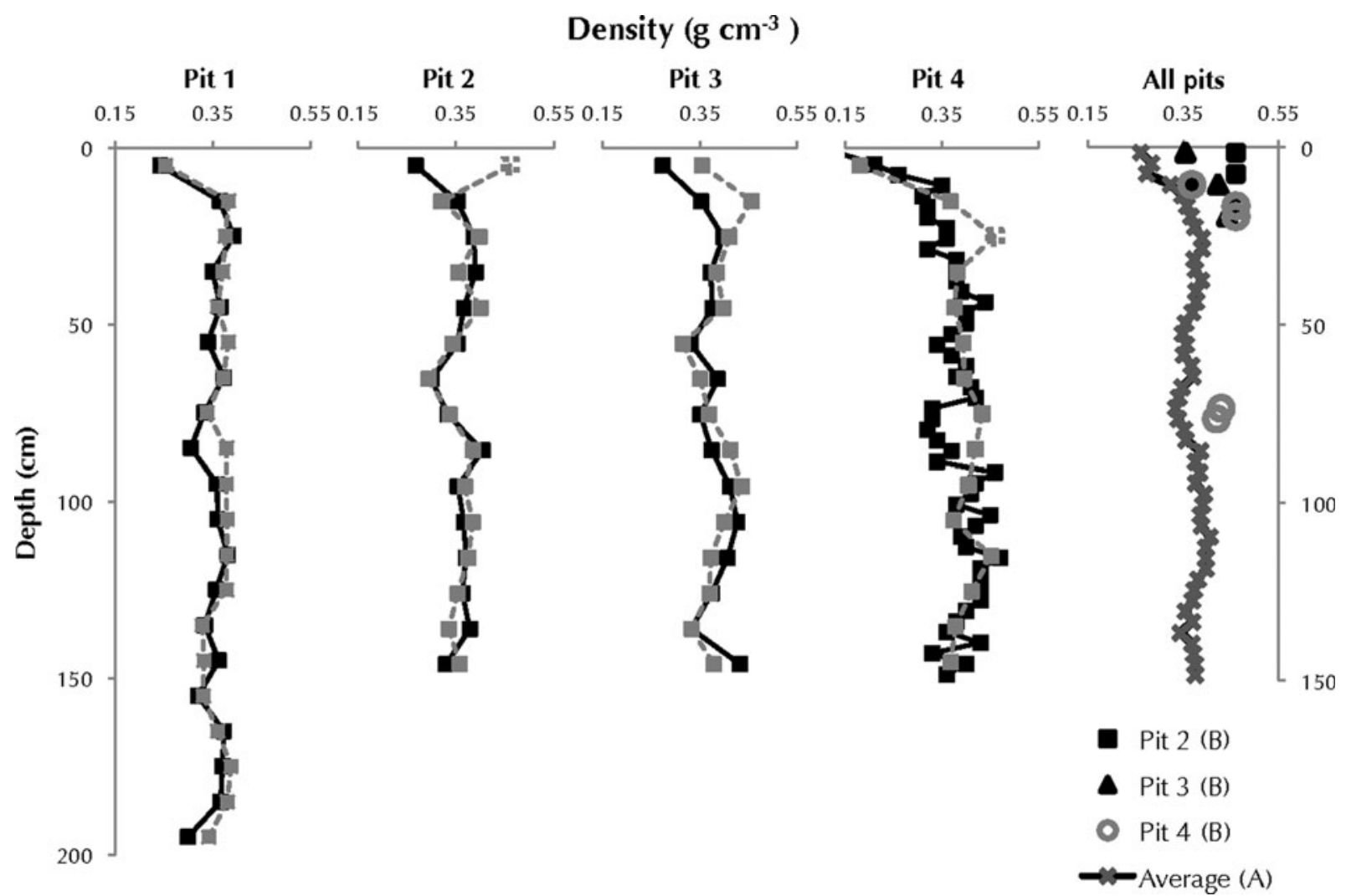

Fig. 4. Density $\left(\mathrm{g} \mathrm{cm}^{-3}\right)$ versus depth for each profile $(A$ and $B)$ in each snow pit. Pristine snow (profile A) is in solid black, and melt-affected snow (profile B) is in grey. Intervals along profile B where melt features prevented full insertion of the density cutter were approximated (see Methods), and these are shown with dashed grey boxes. The fifth column plots mean densities $\left(\mathrm{g} \mathrm{cm}^{-3}\right)$ derived from the four pristine snowpit profiles (A) versus depth. Symbols mark profile B samples that depart from the mean density of four A profiles beyond the 95\% confidence interval. The grouping of significant density changes in the top $25 \mathrm{~cm}$ of pits $2-4$ suggests a similar pattern of meltwater penetration. Pit 4 has another interval of significant density change at $\sim 75 \mathrm{~cm}$ depth.

adjacent, melt-affected profile B. This apparent retrograde motion of peak centres could be either a manifestation of efficient transport of material down-pit or an artefact of possible sampling offset. Therefore, we calculate and plot lagged comparisons between profiles A and B, with seasonal signals in adjacent profiles nominally centred on peak values (Fig. 6). This conservative approach addresses possible sampling errors and focuses the significance testing to distinguish between variations in seasonal deposition and meltwater transport.

Table 1. The main statistics of the trace-element concentrations measured in our four snow pits split into groupings of pristine snow (profile A) and meltwater-treated snow (profile B). The distribution of means and maximum values for profile A are statistically different from those in profile B ( $p$-value of 0.038 at $\alpha=0.05$ ). Except for Fe and $\mathrm{Co}$, the average decrease in mean concentration for the four snow pits was $0.49-8.05 \%$. Seasonal peak concentrations were greater in 2010 than in 2009, and the systematic diminution of average and maximum concentration values suggests a melt effect whereby meltwater intrusion removes trace elements from the 2010 peak and redistributes them in the depth interval between the 2010 and 2009 seasonal peaks

\begin{tabular}{|c|c|c|c|c|c|c|c|c|}
\hline \multirow[b]{2}{*}{ Element } & \multicolumn{4}{|c|}{ Profile A } & \multicolumn{4}{|c|}{ Profile B } \\
\hline & Mean & SD & Median & Max & Mean & SD & Median & Max \\
\hline $\operatorname{Sr}\left(n g L^{-1}\right)$ & 45.406 & 68.968 & 16.063 & 524.073 & 43.307 & 56.259 & 18.030 & 299.046 \\
\hline $\operatorname{Cs}\left(\operatorname{ng~L}^{-1}\right)$ & 0.898 & 1.213 & 0.359 & 7.213 & 0.843 & 1.058 & 0.368 & 5.720 \\
\hline $\operatorname{La}\left(n g L^{-1}\right)$ & 2.036 & 3.250 & 0.764 & 25.300 & 1.879 & 2.430 & 0.834 & 11.970 \\
\hline $\mathrm{Ce}\left(\mathrm{ng} \mathrm{L}^{-1}\right)$ & 4.617 & 7.224 & 1.688 & 54.982 & 4.252 & 5.350 & 1.934 & 25.375 \\
\hline $\operatorname{Pr}\left(\mathrm{ng} \mathrm{L}^{-1}\right)$ & 0.542 & 0.834 & 0.214 & 6.588 & 0.498 & 0.621 & 0.230 & 2.995 \\
\hline $\mathrm{Al}\left(\mu \mathrm{g} \mathrm{L}^{-1}\right)$ & 2.637 & 2.761 & 1.593 & 19.341 & 2.624 & 2.231 & 1.744 & 11.373 \\
\hline $\mathrm{Ca}\left(\mu \mathrm{gL}^{-1}\right)$ & 6.405 & 8.968 & 2.774 & 83.909 & 6.124 & 7.024 & 3.054 & 44.637 \\
\hline $\mathrm{Ti}\left(\mathrm{ng} \mathrm{L}^{-1}\right)$ & 76.264 & 101.646 & 41.099 & 698.180 & 73.182 & 85.627 & 43.692 & 529.077 \\
\hline$M n\left(n g L^{-1}\right)$ & 79.394 & 113.199 & 33.076 & 904.349 & 76.502 & 91.962 & 36.555 & 462.640 \\
\hline $\mathrm{Fe}\left(\mu \mathrm{gL}^{-1}\right)$ & 2.025 & 2.751 & 0.941 & 18.742 & 2.270 & 2.882 & 1.083 & 18.760 \\
\hline $\mathrm{Co}\left(\mathrm{ng} \mathrm{L}^{-1}\right)$ & 1.477 & 1.834 & 0.774 & 12.857 & 1.565 & 2.227 & 0.774 & 26.015 \\
\hline$M g\left(\mu g L^{-1}\right)$ & 2.786 & 2.481 & 1.838 & 17.581 & 2.769 & 2.023 & 1.978 & 12.600 \\
\hline
\end{tabular}


Pit 1

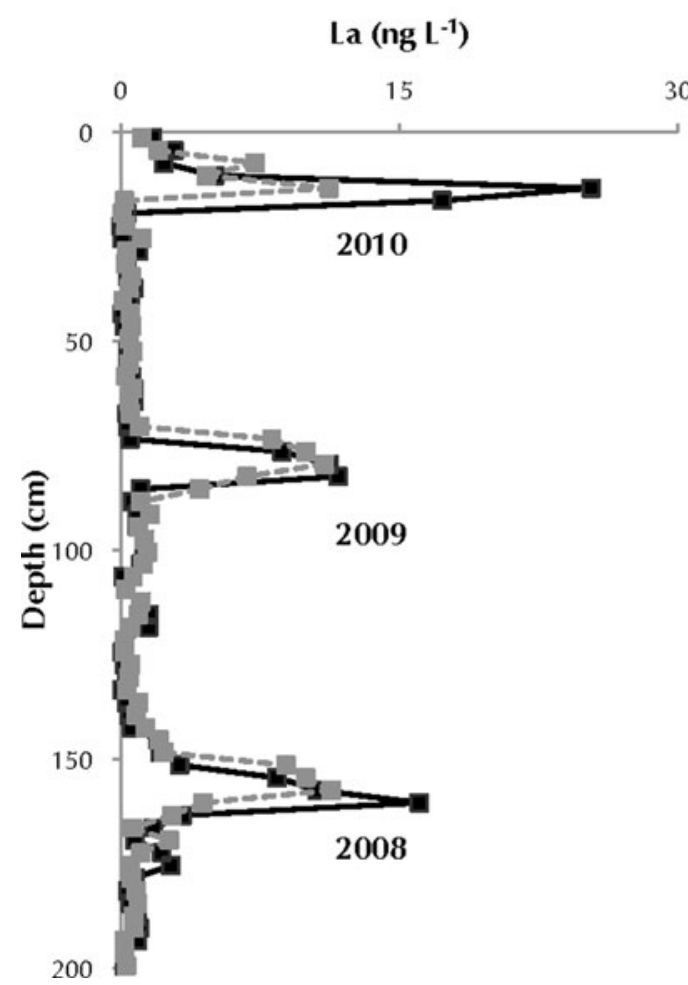

Pit 2

300

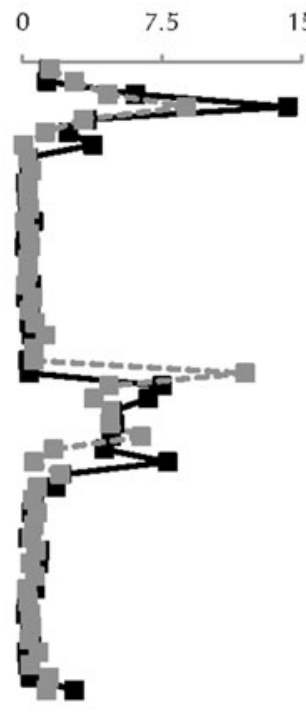

Pit 3

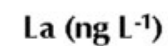

Pit 4

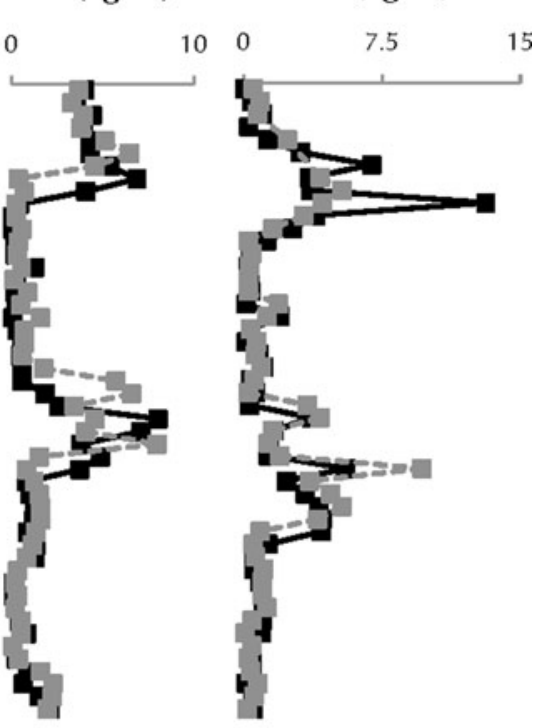

Fig. 5. Lanthanum concentration ( $\mathrm{ng} \mathrm{L}^{-1}$ ) versus depth for each profile in each snow pit. La is displayed because it behaved consistently in this series of experiments. Profile A is solid black, and profile B is grey. All eight profiles exhibit the strong seasonality of dust deposition at Summit, with springtime peaks from Asian dust influx and relatively low concentrations throughout the rest of the year (Whitlow and others, 1992; Biscaye and others, 1997; Bory and others, 2002). Each spring peak is labeled by the year in which it fell.

Our results indicate a consistent pattern across the four snow pits: as depth increases, the sign of the difference in adjacent profiles (B minus $\mathrm{A}$ ) transitions from negative to positive (Fig. 6). Depletion of mass and diminution of concentrations in the melt-affected profiles occur in the upper third of the snow pit (Fig. 6). As the centre of the analysis window moves down-pit to the middle third of a snow pit ( $50 \mathrm{~cm}$; just below the 2010 springtime peak), the sign of the difference becomes positive, indicating an addition of mass and increase in concentrations in the melt-affected profile relative to the pristine profile. The signs of the differences near the bottom third of a snow pit imply neither addition nor removal of mass. Direction of mass transport can be deduced from the sign of the difference between profiles A and B (Fig. 6). Note that while the frequency of significant differences in pits 2-4 decreases when the more conservative analysis is employed, the sign and stratigraphic location of the remaining occurrences agree with the non-lagged analysis.

Analogous to our comparison of density changes to identify zones of potential meltwater-induced mass movement, we use significant differences in concentrations (or masses) between profiles in a single snow pit to locate areas where meltwater migration vertically transported trace elements. Figure 6 shows depth ranges where the trace elements demonstrate significant melt-affected behaviour. Pits 1-3 demonstrate significant changes within $50 \mathrm{~cm}$ analysis windows effectively centred about $\sim 53 \mathrm{~cm}$ depth, which includes samples between 25 and $80 \mathrm{~cm}$. Pit 4, which was sampled 33 days after the first three snow pits, exhibits similar behaviour centred about $\sim 72 \mathrm{~cm}$ depth, which includes samples between 40 and $100 \mathrm{~cm}$.

\section{Comparing physical snowpack changes with changes in snow chemistry}

Changes in trace-element distribution attributed to meltwater mobilization correspond to measured density changes and visually observed areas of refreezing. Both the observed melt features and the significant changes in measured density indicate that the top $25 \mathrm{~cm}$ of pits 2-4 experienced significant meltwater intrusion and refreezing. One depth where a significant density difference is located in an area with no observed melt features is $75 \mathrm{~cm}$ in pit 4 . We measured a density in profile B that was significantly different from the mean of A profiles, but did not see evidence of melt intrusion on the snow-pit wall (Fig. 2). Similarly, differences in trace-element chemistry identify a $50 \mathrm{~cm}$ wide window, effectively centred at $\sim 53 \mathrm{~cm}$ depth, where it is likely meltwater has percolated through. Physical observations of pits 2-4 agree, but physical observations do not capture the potential melt-affected snow in pit 1 . Here no melt features were observed below $3 \mathrm{~cm}$ despite the signature of melt found in the trace-element chemistry. The most inclusive measure of melt presence in the near-surface snow is the change observed in the trace-element chemistry of melt-affected snow.

\section{DISCUSSION}

\section{Physical snowpack changes resulting from melt percolation}

We observed preferential meltwater percolation in the vertical direction in addition to horizontal flow in all four snow pits (Marsh and Woo, 1984; Bøggild and others, 2005; 


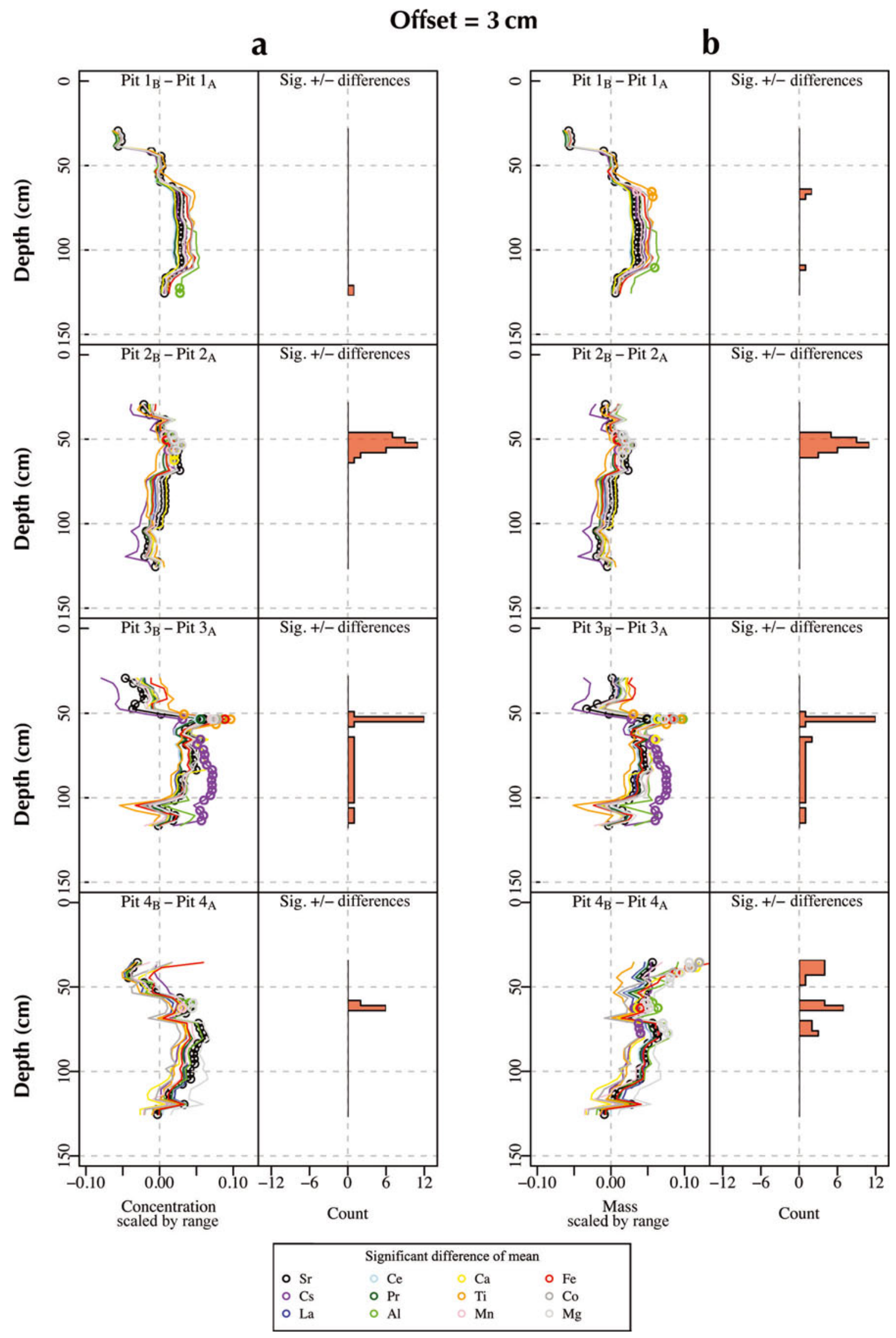

Fig. 6. Mean differences of paired pristine and melt-affected profiles, derived using $50 \mathrm{~cm}$ moving windows. Points along each profile mark locations where a $t$-test procedure identified these mean differences to be significantly larger than the natural variance estimated from the same stratigraphic segment of the two nearest pristine profiles (at the $95 \%$ confidence level). (a) Mean differences in concentrations for the four snow pits. The left column displays the mean difference of profile A from profile B (by element) for each pit, and the right column displays the number of elements demonstrating a statistically significant difference for each step of the analysis window. (b) Mean differences between calculated masses for the four snow pits, with the columns displaying similar information to that in (a). Typically, a significant difference between concentrations corresponds to a significant difference between masses, though that is not always the case (e.g. pit 4). 
Das and Alley, 2005). Despite constraining our study to one location (Summit, Greenland), melt features presented themselves dissimilarly across the four snow pits. Vertical ice fingers reached depths of 75 and $135 \mathrm{~cm}$ in pits 2 and 3, respectively. Less vertical transport is observed in pits 1 and 4 . There was evidence of refreeze in the top $3 \mathrm{~cm}$ of pit 1 and there was horizontal refreeze present between 6 and $24 \mathrm{~cm}$ in pit 4 . Meltwater perturbation to snowpack physical and chemical properties in this study has been observed to be heterogeneous.

We observed consequent density changes with the presence of melt features, but accurately resolving all density changes resulting from refrozen meltwater is challenging. We were unable to sample density in some areas of thickly refrozen meltwater in pits 2 and 4 . Additionally, vertical meltwater flow penetrated the snowpack more deeply in pits 2 and 3 (Fig. 2) than their respective deepest significant density change. This suggests our density sampling resolution under-sampled melt-affected areas. Meltwater may have percolated down to $\sim 150 \mathrm{~cm}$ depth in all four snow pits, as it did in pit 3 . An addition of $15 \mathrm{~L}$ of meltwater distributed evenly over the depth of each snow pit $(\sim 150 \mathrm{~cm})$ would amount to a mean density increase of $0.01 \mathrm{~g} \mathrm{~cm}^{-3}$, which is smaller than the pre-existing variations in density.

\section{Snow chemistry changes due to natural variability and melt}

Major factors influencing chemical concentrations in snow on polar ice sheets include distance inland, elevation and snow accumulation rate (Mulvaney and Wolff, 1994; Yang and others, 1996). Secondary factors such as seasonality of deposition and surface roughness contribute to a lesser degree. We minimize the effects of the major factors by focusing on snow-pit chemistry changes at the $10 \mathrm{~m}$ scale. At Summit, Greenland, Albert and Hawley (2002) observed surface roughness amplitudes of $3-8 \mathrm{~cm}$ for most of the year, with a late-winter increase to $20 \mathrm{~cm}$. Fisher and others (1985) have modelled how increased surface roughness at a site increases the deviations in measured accumulation between two adjacent points. The surface roughness seen at Summit may explain the large difference in peak concentrations and total mass of elements between pit 1 and the other snow pits. Extending this modelled signal variance, which incorporates measured deviations in accumulation, to measured snow chemistry must account for post-depositional processes.

Performing intra-pit comparisons between profiles only $50 \mathrm{~cm}$ apart diminishes the influence of variable surface roughness and increases the likelihood that the difference between any two samples or subsets of samples reflects actual chemistry changes resulting from meltwater percolation and refreeze. A moving $50 \mathrm{~cm}$ vertical analysis window helps further smooth potential variability. However, any analysis that depends on depth-paired samples is sensitive to small depth variations in seasonal peaks of element concentration or mass. The apparent $\sim 3 \mathrm{~cm}$ offset seen in heights between paired profiles would produce such an edge effect. If we assume the apparent $\sim 3 \mathrm{~cm}$ offset is due to sampling error and not due to meltwater mass transport, which may or may not be the case, we can eliminate the offset by lagging one series to reduce this edge effect. Comparing the results between unlagged and lagged differences indicates the apparent offset is not a factor in all snow pits, and that pits 2-4 show true mass transport from one seasonal peak to the previous year's seasonal peak.

We interpret significant snow chemistry differences in the snow pits to be melt-caused, and these differences do not always coincide with physically observable melt features. Changes in chemistry due to melt percolation and refreezing were identified based on the variance defined by nearestneighbour pairs. Chemically determined depths of melt intrusion appear to be more inclusive than the physical observations and digital imagery. This could reflect the heterogeneity of meltwater percolation and how water may intrude into spaces just behind a snow-pit wall. While there is no visual evidence of melt modification, the chemistry is sensitive to meltwater presence. Previous laboratory studies demonstrated an enrichment of filtered trace elements in the early fraction of snowmelt (Abrahams and others, 1988), and Waldner and others (2004) describe a flow regime (matrix flow) where the transition from a pendular liquid phase arrangement to a funicular arrangement does not visually manifest itself with macroscopic heterogeneities. Movement of meltwater in the microstructure, while potentially enriched in trace elements, may not be visible in the macroscale. Physical effects of melt were not always observed in conjunction with melt-affected snow chemistry. Studies of melt-prone glaciers may not fully account for melt if the only tools used to determine melt presence are comparisons of observed physical characteristics. This suggests connecting higher-resolution density measurements with improved analytical chemistry techniques to more accurately determine the melt history of a site.

The large window overlap of our statistical analysis aids in determining the 'sign' of mass movement. Negative differences between profiles A and B suggest mass has been removed from profile $B$ at the indicated depth(s) and is being eluted down-pit. Positive differences indicate the depths where mobile elements are settling via meltwater refreezing. This pattern of negative differences near the top of our snow pits and positive differences in the middle of our snow pits, when coupled with the physical observations of the snow pits, is more diagnostic of melt effect in near-surface snow than either measurement on its own.

\section{Effect of melt percolation on dust trace elements}

Despite the application of $15 \mathrm{~L}$ of meltwater, equivalent to an approximate melt index of $10 \%$, seasonal stratigraphic peaks of dust trace elements remain roughly in place and clearly evident. Our data indicate transport of mass is most significant in the depth range between the 2010 and 2009 springtime dust aerosol peaks, or in snow that had fallen the previous summer and winter. Diminution of trace-element concentrations (e.g. $19-47 \%$ in ${ }^{139}$ La) still allows for snow chemistry peak identification in our experiments due to relatively low summer-fall background concentrations at Summit. Thus, consistent seasonal phenomena make trace elements an excellent parameter to use in dating ice cores, even in the presence of an artificially applied ice melt percentage of nearly $10 \%$. Determining the effect of progressively larger volumes of meltwater in similar experiments may identify critical thresholds above which such seasonal oscillations are lost.

Much has been done investigating the origin and provenance of dust at Summit, Greenland (e.g. Whitlow and others, 1992; Biscaye and others, 1997; Drab and others, 2002), since insoluble particles can serve as tracers 
for atmospheric turbidity. Our data suggest that certain elements of dust can serve as tracers for meltwater percolation. In our four melt experiments, certain trace elements (e.g. ${ }^{88} \mathrm{Sr},{ }^{139} \mathrm{La},{ }^{140} \mathrm{Ce},{ }^{141} \mathrm{Pr},{ }^{47} \mathrm{Ti}$ ) demonstrated lower mobility (i.e., showing fewer statistically significant differences between profiles A and B), while others (e.g. ${ }^{44} \mathrm{Ca}$ and ${ }^{24} \mathrm{Mg}$ ) exhibited higher mobility. The behaviour of ${ }^{139} \mathrm{La},{ }^{140} \mathrm{Ce}$ and ${ }^{141} \mathrm{Pr}$ suggests that the limited mobility of rare earth elements (REEs) within the snowpack, even in the presence of meltwater, would make them ideal reference elements to evaluate melt proportion. Similar to the use of $\mathrm{Na}^{+}$and $\mathrm{Mg}^{2+}$ in indicating melt in other Arctic ice cores (e.g. lizuka and others, 2002; Virkkunen and others, 2007), REEs in comparison with the more mobile ${ }^{44} \mathrm{Ca}$ or ${ }^{24} \mathrm{Mg}$ may serve as melt indicators. As there are currently limited REE data from melt-affected regions, more trace-element characterizations of firn and ice cores drilled in melt-prone areas may elucidate this preferential mobilization.

Most ice cores collected on small glaciers and ice caps outside Greenland and Antarctica are affected by melt, and understanding the impact of melt percolation on traceelement chemistry becomes critical when those elements are used in proxies without regard to their potential mobility. This specifically has implications for how the trace-element budget of an ice core is affected by meltwater percolation. Most trace elements measured are associated with mineral dusts, as in the case of ${ }^{139} \mathrm{La}$, which are not soluble in water. Moreover, as we are leaching each melted sample in a dilute acid solution, the measured trace-element concentrations likely contain only partial mineral dust dissolution from mostly oxides and sheet silicates (Osterberg and others, 2006; Rhodes and others, 2011). Our data, while representative of the mineral dust concentration in our snow samples, are not meant to construct meaningful crustal enrichment factor values without some assessment of the degree of uncertainty associated with incongruent microparticle leaching. This determination is beyond the scope of this study.

Our data show how surface melt can significantly perturb the trace-element snow chemistry. Seasonal changes are still present in our melt experiments, but chemistry peaks may move relative to where they were initially deposited. Severe melt events can affect estimates of accumulation rates if relatively mobile trace elements (e.g. ${ }^{44} \mathrm{Ca}$ ) are used as a reference element. Koerner (1977) and Steffensen (1985) discuss microparticle migration and possible size fractionation in the presence of melt. Smaller microparticles made mobile by meltwater would effectively shift seasonal peaks in measured concentrations down-pit relative to a hypothetical snowpack with no melt. Similarly, Waldner and others (2004) relate solute transport efficiency to microstructure, noting how the boundary between a fine- and a coarse-textured snow layer acts as a barrier for meltwater. Seasonal differences in average grain size across the depth interval containing the 2009 chemistry peak may explain why mass movement became less significant beyond the 2009 spring dust peak. One possibility is the coarse, 2009 summer grains act as a capillary boundary, impeding further down-pit movement of mobilized microparticles. Microparticles that were mobilized by percolating meltwater would collect at such transitions and make their 2009 seasonal trace-element chemistry peaks appear to occur later relative to less mobile trace elements. Quantifying microparticle densities and size distributions to investigate this is beyond the scope of this paper.

\section{Summit study site compared to melt-prone Arctic sites}

It is informative to see how our study area at Summit, Greenland, compares with other Arctic research sites that experience melt. Most ice cores extracted from the Arctic exhibit an ice column comprising $50 \%$ or more of bubble-free ice formed by melt, infiltration and refreezing (Koerner, 1997). Assuming meltwater refreezes within its originating annual layer, a melt index of $50 \%$ indicates an average melt of $33 \%$ of the annual accumulation. Warmer glaciers (e.g. Austfonna, Svalbard) could see effective percolation depths beyond an annual layer (lizuka and others, 2002). Our study site (10\% melt percentage of annual accumulation; $11 \%$ melt index) falls within a range defined by many well-characterized, melt-prone Arctic ice-core sites: Agassiz Ice Cap, Canada, 3\%; Penny Ice Cap 40\%; Lomonosovfonna, Svalbard, 3050\%; and Austofonna 67\% (Koerner, 1997; Goto-Azuma and others, 2002; Pohjola and others, 2002; Virkkunen and others, 2007). Summit's accumulation rate $\left(24.0 \mathrm{~cm}\right.$ w.e. $\left.\mathrm{a}^{-1}\right)$ is within the range of these Arctic sites: Agassiz Ice Cap, $15 \mathrm{~cm}$ w.e. $\mathrm{a}^{-1}$; Penny Ice Cap, $33 \mathrm{~cm}$ w.e. $\mathrm{a}^{-1}$; Lomonosovfonna, $36 \mathrm{~cm}$ w.e. $\mathrm{a}^{-1}$; and Austofonna, $50-60 \mathrm{~cm}$ w.e. $\mathrm{a}^{-1}$ (Goto-Azuma and Koerner, 2001; lizuka and others, 2002; Pohjola and others, 2002). Summit's mean temperature $\left(-32^{\circ} \mathrm{C}\right)$ is the coldest of these Arctic sites: Agassiz Ice Cap, $-24.5^{\circ} \mathrm{C}$; Penny Ice Cap, $-16.6^{\circ} \mathrm{C}$; Lomonosovfonna, $-12.5^{\circ} \mathrm{C}$ (Goto-Azuma and Koerner, 2001; Pohjola and others, 2002).

An obvious question is the degree to which our results from artificial melt experiments at Summit are applicable to glaciers with natural melt and different mean annual temperatures or accumulation. The parameter that is least like other melt-prone Arctic sites is Summit's low mean annual temperature. Our experiments demonstrate artificial meltwater penetration into the 2009 annual layer despite the inherently cold snowpack. Higher mean annual temperatures at other glaciers imply a warmer snowpack, which increases the likelihood of surface-borne meltwater percolating down beyond just one annual layer. While these vertical conduits promote downward transport of soluble elements, thereby diminishing retention of majorion seasonality, insoluble mobility would be more limited based on microparticle size, snow microstructure and seasonal snowpack temperature gradient. Even in study areas with large melt indices and small near-surface temperature gradients based on warm mean annual temperatures, it is unlikely that particle-bound trace elements will become highly mobilized. Despite the large difference in mean annual temperatures, our observation of limited mobility in insoluble trace elements will likely be reflected in warmer, more melt-prone ice-core sites. Thus, Arctic sites with high melt indices (e.g. Penny Ice Cap and Svalbard) could preserve seasonality in dust-derived trace elements, though melt indices greater than 50\% imply both downward percolation and meltwater runoff. Mean annual accumulation and dominant aerosol source are important, with Summit considered to be a high-accumulation site with a strong seasonal dust signal. Our measurements of REEs associated with dust support our conclusion that while there is mass transport with meltwater percolation, the seasonal signal is well preserved. Coastal sites would likely need strong dust seasonality to allow interpretation of traceelement chemistry on an annual scale. 


\section{CONCLUSIONS}

We have shown that meltwater percolation and refreezing perturbs the dust trace-element snow chemistry by transporting mass downward where it refroze into the snowpack. This melt effect tends to diminish the element concentrations (e.g. $11-47 \%$ in ${ }^{88} \mathrm{Sr}$ ) within the source accumulation year and increase the concentrations (e.g. $1-32 \%$ in ${ }^{88} \mathrm{Sr}$ ) in the snowpack above the previous seasonal peak. This analysis of melt effect accounts for the natural variability inherent to our study site and identifies depths where significant differences between pristine and melt-affected snow chemistry are present through a moving-window statistical technique. Despite the presence of meltwater intrusion, the seasonal chemical signal is clearly preserved within the four snow pits examined in this study. Therefore, our study shows that dust trace elements retain their annual stratigraphy and can be used as a dating parameter even in ice cores affected by nearly $10 \%$ annual melt percentage.

Meltwater infiltration into the near surface is heterogeneous and challenging to document. We have shown here that traditional density measurements or visual inspection, by themselves, do not conclusively identify melt in our study area. In areas where the annual melt percentage is somewhat greater than $10 \%$ (e.g. smaller mountain glaciers or mid-latitude ice caps), trace-element redistribution by way of microparticle migration will likely follow the same pattern as in our experiment. Identification and characterization of melt as it pertains to atmospheric influence as well as near-surface mass balance can occur using a combination of physical and chemical analyses. As a site's annual melt percentage approaches $100 \%$, however, the snowpack structure will degrade to the point where chemical constituents, soluble or otherwise, become well mixed and annual stratigraphy is compromised.

Results from our melt experiment at Summit, Greenland, have practical applications to both melt-prone ice-core sites and ice-core sites that experience episodic melt. Primarily, meltwater percolation does not affect gross seasonality of dust-related trace elements. Higher mean annual temperatures in melt-prone Arctic ice-core sites will imply greater downward mobility of major ions, soluble trace elements and some insoluble trace elements, but particle-bound elements (especially REEs) will be relatively immobile and retain their annual signal. A key component in determining the site's potential for annual signal retention is characterizing dominant aerosol sources. Strong dust seasonality is necessary to ensure adequate signal retention. As improved detection limits allow for more detailed examinations of snow and ice chemistry, the use of trace elements as an indicator for melt effects, in conjunction with other chemistry proxies and physical observations, may uncover more complex melt histories at melt-affected ice-core sites.

\section{ACKNOWLEDGEMENTS}

Funding for this work was provided by the US National Science Foundation's Arctic Natural Sciences Program Award ARC-0909265 and IGERT Program Award DGE-0801490. We thank two reviewers and the editors for insightful comments which greatly improved the paper. We also thank everyone, from field personnel to laboratory technicians, who helped with this work. In particular, we thank Zoe Courville, Xiahong Feng, Dave Ferris, Mike Handley, Eric Posmentier, Ross Virginia, CH2M HILL Polar Services, the US
Army Cold Regions Research and Engineering Laboratory, Dartmouth College Department of Earth Sciences, the Dartmouth College Integrative Graduate Education and Research Traineeship (IGERT) - Cohort 1 Summer Seminar, the EARS Glaciology Research Group, the US Air National Guard 109th Airlift Wing, 8Low, and the folks who support Kangerlussuaq and Summit.

\section{REFERENCES}

Abrahams PW, Tranter M, Davies TD, Blackwood IL and Landsberger $S$ (1988) Trace-element studies in a remote Scottish upland catchment. Water, Air, Soil Pollut., 37(3-4), 255-271 (doi: 10.1007/BF00192939)

Albert MR and Hawley RL (2002) Seasonal changes in snow surface roughness characteristics at Summit, Greenland: implications for snow and firn ventilation. Ann. Glaciol., 35, 510-514 (doi: 10.3189/172756402781816591)

Alley RB and Anandakrishnan S (1995) Variations in melt-layer frequency in the GISP2 ice core: implications for Holocene summer temperatures in central Greenland. Ann. Glaciol., 21, 64-70

Benson CS (1962) Stratigraphic studies in the snow and firn of the Greenland ice sheet. SIPRE Res. Rep. 70, 76-83

Bigler M, Svensson A, Kettner E, Vallelonga P, Nielsen ME and Steffensen JP (2011) Optimization of high-resolution continuous flow analysis for transient climate signals in ice cores. Environ. Sci. Technol., 45(10), 4483-4489 (doi: 10.1021/es200118j)

Biscaye PE and 6 others (1997) Asian provenance of glacial dust (stage 2) in the Greenland Ice Sheet Project 2 ice core, Summit, Greenland. J. Geophys. Res., 102(C12), 26765-26781 (doi: 10.1029/97JC01249)

Bøggild CE, Forsberg $\mathrm{R}$ and Reeh N (2005) Meltwater retention in a transect across the Greenland ice sheet. Ann. Glaciol., 40, 169-173 (doi: 10.3189/172756405781813546)

Bory AJM, Biscaye PE, Svensson A and Grousset FE (2002) Seasonal variability in the origin of recent atmospheric mineral dust at NorthGRIP, Greenland. Earth Planet. Sci. Lett., 196(3-4), 123-134 (doi: 10.1016/S0012-821X(01)00609-4)

Bory AJM, Biscaye PE, Piotrowski AM and Steffensen JP (2003) Regional variability of ice core dust composition and provenance in Greenland. Geochem. Geophys. Geosyst., 4(12), 1107 (doi: 10.1029/2003GC000627)

Boutron CF, Candelone JP and Hong SM (1994) Past and recent changes in the large-scale tropospheric cycles of lead and other heavy metals as documented in Antarctic and Greenland snow and ice: a review. Geochim. Cosmochim. Acta, 58(15), 3217-3225 (doi: 10.1016/0016-7037(94)90049-3)

Brimblecombe P, Tranter M, Abrahams PW, Blackwood I, Davies TD and Vincent CE (1985) Relocation and preferential elution of acidic solute through the snowpack of a small, remote, high-altitude Scottish catchment. Ann. Glaciol., 7, 141-147

Clausen HB, Gundestrup NS, Johnsen SJ, Bindschadler R and Zwally J (1988) Glaciological investigations in the Crête area, central Greenland: a search for a new deep-drilling site. Ann. Glaciol., 10, 10-15

Das SB and Alley RB (2005) Characterization and formation of melt layers in polar snow: observations and experiments from West Antarctica. J. Glaciol., 51(173), 307-313 (doi: 10.3189/ 172756505781829395)

Das SB and Alley RB (2008) Rise in frequency of surface melting at Siple Dome through the Holocene: evidence for increasing marine influence on the climate of West Antarctica. J. Geophys. Res., 113(D2), D02112 (doi: 10.1029/2007JD008790)

Davies TD, Vincent CE and Brimblecombe P (1982) Preferential elution of strong acids from a Norwegian ice cap. Nature, 300(5888), 161-163 (doi: 10.1038/300161a0)

Drab E, Gaudichet A, Jaffrezo JL and Colin JL (2002) Mineral particles content in recent snow at Summit (Greenland). Atmos. Environ., 36(34), 5365-5376 (doi: 10.1016/S1352-2310(02)00470-3) 
Fisher DA, Reeh N and Clausen HB (1985) Stratigraphic noise in the time series derived from ice cores. Ann. Glaciol., 7, 76-83

Fortner SK, Lyons WB, Fountain AG, Welch KA and Kehrwald NM (2009) Trace element and major ion concentrations and dynamics in glacier snow and melt: Eliot Glacier, Oregon Cascades. Hydrol. Process., 23(21), 2987-2996 (doi: 10.1002/hyp.7418)

Goto-Azuma K and Koerner RM (2001) Ice core studies of anthropogenic sulfate and nitrate trends in the Arctic. J. Geophys. Res., 106(D5), 4959-4969

Goto-Azuma K, Koerner RM and Fisher DA (2002) An ice-core record over the last two centuries from Penny Ice Cap, Baffin Island, Canada. Ann. Glaciol., 35, 29-35 (doi: 10.3189/ 172756402781817284)

Hanna E and 8 others (2008) Increased runoff from melt from the Greenland Ice Sheet: a response to global warming. J. Climate, 21(2), 331-341

Herron MM, Herron SL and Langway, CC, Jr (1981) Climatic signal of ice melt features in southern Greenland. Nature, 293(5831), 389-391 (doi: 10.1177/095968369300300409)

Hong S, Candelone JP, Patterson CC and Boutron CF (1994) Greenland ice evidence of hemispheric lead pollution two millennia ago by Greek and Roman civilizations. Science, 265(5180), 1841-1843

Hong S, Candelone J-P, Turetta C and Boutron CF (1996) Changes in natural lead, copper, zinc and cadmium concentrations in central Greenland ice from 8250 to 149,100 years ago: their association with climatic changes and resultant variations of dominant source contributions. Earth Planet. Sci. Lett., 143(1-4), 233-244 (doi: 10.1016/0012-821X(96)00137-9)

lizuka Y, Igarashi M, Kamiyama K, Motoyama $\mathrm{H}$ and Watanabe $\mathrm{O}$ (2002) Ratios of $\mathrm{Mg}^{2+} / \mathrm{Na}^{+}$in snowpack and an ice core at Austfonna ice cap, Svalbard, as an indicator of seasonal melting. J. Glaciol., 48(162), 452-460 (doi: 10.3189/ 172756502781831304)

Kelsey EP, Wake CP, Kreutz K and Osterberg E (2010) Ice layers as an indicator of summer warmth and atmospheric blocking in Alaska. J. Glaciol., 56(198), 715-722 (doi: 10.3189/002214310793146214)

Koerner RM (1977) Devon Island ice cap: core stratigraphy and paleoclimate. Science, 196(4285), 15-18

Koerner RM (1997) Some comments on climatic reconstructions from ice cores drilled in areas of high melt. J. Glaciol., 43(143), 90-97

Lambert F and 9 others (2008) Dust-climate couplings over the past 800,000 years from the EPICA Dome C ice core. Nature, 452(7187), 616-619 (doi: 10.1038/nature06763)

Langway CC, Jr (1967) Stratigraphic analysis of a deep ice core from Greenland. CRREL Res. Rep. 77.

Legrand M and Mayewski P (1997) Glaciochemistry of polar ice cores: a review. Rev. Geophys., 35(3), 219-243 (doi: 10.1029/ 96RG03527)

Liu Y, Hou S, Hong S, Soon DH, Lee K and Wang Y (2011) Highresolution trace element records of an ice core from the eastern Tien Shan, central Asia, since 1953 AD. J. Geophys. Res., 116(D12), D12307 (doi: 10.1029/2010JD015191)

Lutz E, Birkeland KW, Kronholm K, Hansen K and Aspinall R (2007) Surface hoar characteristics derived from a snow micropenetrometer using moving window statistical operations. Cold Reg. Sci. Technol., 47(1-2), 118-133 (doi: 10.1016/j.coldregions. 2006.08.021)

Marsh P and Woo MK (1984) Wetting front advance and freezing of meltwater within a snow cover. 2. A simulation model. Water Resour. Res., 20(12), 1865-1874

McConnell JR, Lamorey GW, Lambert SW and Taylor KC (2002) Continuous ice-core chemical analyses using inductively coupled plasma mass spectrometry. Environ. Sci. Technol., 36(1), 7-11 (doi: 10.1021/es011088z)

McGurk BJ and Kattelmann RC (1988) Transport of liquid water: flow finger evidence from thick-section photography. Eos, 69(44), 1204
Meese DA and 8 others (1994) The accumulation record from the GISP2 core as an indicator of climate change throughout the Holocene. Science, 266(5191), 1680-1682 (doi: 10.1126/ science.266.5191.1680)

Mosher BW, Winkler P and Jaffrezo JL (1993) Seasonal aerosol chemistry at Dye 3, Greenland. Atmos. Environ., 27A(17-18), 2761-2772 (doi: 10.1016/0960-1686(93)90308-L)

Mulvaney R and Wolff EW (1994) Spatial variability of the major chemistry of the Antarctic ice sheet. Ann. Glaciol., 20, 440-447

Murozumi M, Chow TJ and Patterson CC (1969) Chemical concentrations of pollutant lead aerosols, terrestrial dusts and sea salts in Greenland and Antarctic snow strata. Geochim. Cosmochim. Acta, 33(10), 1247-1294 (doi: 10.1016/0016-7037(69)90045-3)

Narcisi B, Petit JR and Tiepolo M (2006) A volcanic marker (92 ka) for dating deep east Antarctic ice cores. Quat. Sci. Rev., 25(21-22), 2682-2687 (doi: 10.1016/j.quascirev.2006.07.009)

Osterberg EC, Handley MJ, Sneed SB, Mayewski PA and Kreutz KJ (2006) Continuous ice core melter system with discrete sampling for major ion, trace element, and stable isotope analyses. Environ. Sci. Technol., 40(10), 3355-3361

Osterberg E and 10 others (2008) Ice core record of rising lead pollution in the North Pacific atmosphere. Geophys. Res. Lett., 35(5), L05810 (doi: 10.1029/2007GL032680)

Pfeffer WT and Humphrey NF (1998) Formation of ice layers by infiltration and refreezing of meltwater. Ann. Glaciol., 26, 83-91

Pohjola V and 7 others (2002) Effect of periodic melting on geochemical and isotopic signals in an ice core on Lomonosovfonna, Svalbard. J. Geophys. Res., 107(D4), 4036 (doi: 10.1029/ 2000JD000149)

Rhodes RH, Baker JA, Millet M-A and Bertler NAN (2011) Experimental investigation of the effects of mineral dust on the reproducibility and accuracy of ice core trace element analyses. Chemical Geol., 286(3-4), 207-221 (doi: 10.1016/j.chemgeo. 2011.05.006)

Steffensen JP (1985) Microparticles in snow from the South Greenland ice sheet. Tellus, 37B(4-5), 286-295

Steffensen JP (1988) Analysis of the seasonal variation in dust, $\mathrm{Cl}^{-}$, $\mathrm{NO}_{3}{ }^{-}$and $\mathrm{SO}_{4}{ }^{2-}$ in two central Greenland firn cores. Ann. Glaciol., 10, 171-177

Tsiouris S, Vincent CE, Davies TD and Brimblecombe P (1985) The elution of ions through field and laboratory snowpacks. Ann. Glaciol., 7, 196-201

Twickler M and Whitlow S (1997) Appendix B: Guide for the collection and analysis of ITASE snow and firn samples. In Mayewski PA and Goodwin ID eds. International Trans-Antarctic Scientific Expedition (ITASE). Past Global Changes, Bern (PAGES/ SCAR Workshop Report Series 97-1)

Virkkunen K and 6 others (2007) Warm summers and ion concentrations in snow: comparison of present day with Medieval Warm Epoch from snow pits and an ice core from Lomonosovfonna, Svalbard. J. Glaciol., 53(183), 623-634 (doi: 10.3189/ 002214307784409388)

Waldner P, Schneebeli M, Schultze-Zimmermann $\mathrm{U}$ and Flühler $\mathrm{H}$ (2004) Effect of snow structure on water flow and solute transport. Hydrol. Process., 18(7), 1271-1290 (doi: 10.1002/hyp.1401)

Whitlow S, Mayewski PA and Dibb JE (1992) A comparison of major chemical species seasonal concentration and accumulation at the South Pole and Summit, Greenland. Atmos. Environ., 26A(11), 2045-2054 (doi: 10.1016/0960-1686(92)90089-4)

Williams MW, Erickson TA and Petrzelka JL (2010) Visualizing meltwater flow through snow at the centimetre-to-metre scale using a snow guillotine. Hydrol. Process., 24(15), 2098-2110 (doi: 10.1002/hyp.7630)

Yang Q, Mayewski PA, Linder E, Whitlow S and Twickler M (1996) Chemical species spatial distribution and relationship to elevation and snow accumulation rate over the Greenland ice sheet. J. Geophys. Res., 101(D13), 18629-18637 (doi: 10.1029/ 96JD01061)

Zdanowicz CM, Zielinski GA and Wake CP (1998) Characteristics of modern atmospheric dust deposition in snow on the Penny Ice Cap, Baffin Island, Arctic Canada. Tellus, 50B(5), 506-520 